\title{
Exploring the External Causes of Fossilized Pronunciation Errors Employed by English Graduate Students in Classroom Discussion at Universitas Negeri Padang
}

\author{
Vyona Lovenia $^{1, *}$ Jufrizal $^{1}$ \\ ${ }^{1}$ Universitas Negeri Padang, Padang, Indonesia, \\ "Corresponding author.Email: loveniavyona@gmail.com
}

\begin{abstract}
An inevitable phenomenon that tends to occur in acquiring second or foreign language is language fossilization which can occur in every linguistic domain, including speaking. This could happen if there is an error in one of the sub-skills in speaking, especially pronunciation or known as pronunciation fossilization. Apparently, this phenomenon happens to graduate students who have already studied English for years at university. Thus, the aims of this research were to find out the English pronunciation features that tend to be fossilized by the graduate students in classroom discussion and to explore the external causal factor of it. This research was descriptive qualitative research and the data were gathered by doing observation of the process of the classroom discussion and interview to 12 students. The result indicated that all of the sub-factors in external causal factor offered by Han (2003) are causing the students' fossilization. Yet, there are three sub-factors that are the major cause of it. They are the reinforcement from linguistic environment, lack of instruction $\&$ instruction and lack of written input. Moreover, the English pronunciation features that tend be fossilized is vowel and the words are ranging from common words to scientific terms, such as purpose, author, identify, thesis and so forth. It is necessary to know the causal factors of this fossilized pronunciation errors in order to find the method to overcome or resolve the problem.
\end{abstract}

\section{Keywords: Fossilization, Pronunciation Errors, The External Causal Factor, Classroom Discussion}

\section{INTRODUCTION}

The essential of English for various purposes, such as politics and business, has led to a demand for every nonEnglish speaking country to acquire English as its communication tool in order to be able to compete and face the global developments; economy, science, and technology. This explains why English has become one of the prominent subjects to learn in almost every non-English speaking country. In fact, in acquiring English, some of those countries make it as their second language and some others make it as their foreign language (e.g. Indonesia). This fact makes a number of phenomena happened in teaching English as the second language (L2) or as a foreign language.

An inevitable phenomenon that tends to occur in acquiring second or foreign language is language fossilization. Fossilization can occur in every linguistic domain, including speaking. This could happen if there is an error in one of the sub-skills in speaking, especially pronunciation or fossilized pronunciation. Apparently, this phenomenon happens to graduate students who have already studied English for years at university. This fossilization of pronunciation may give a negative effect to the learners' status of proficiency and their professionalism as the academic practitioners, future teachers and model of EFL. It is because pronunciation plays a prominent role in determining the learners' status of proficiency. Hence, fossilized pronunciation features can be a stigmatized marker through which a person's social, professional and educational identity can be determined [1].

Furthermore, it can also affect the learners' professionalism as the academic practitioners, future teachers and model of EFL[2]. Non-native teachers of English should have good pronunciation otherwise it will affect their professionalism at their job in a negative manner. Due to the negative effect it may give sociologically, the researcher is interested to know what are the external factors that cause the graduate students employed fossilized pronunciation errors in classroom discussion and what English pronunciation features that tend to be fossilized.

There have been some conducted researches that deal with fossilization which focus mostly on the identifying the fossilized pronunciation errors of a certain English pronunciation features or sounds and proposing the method to overcome or cure it [1], [3]-[6]. Demirezen [3] explores the causes of the constant mispronunciation of the English schwa phoneme by Turkish English teachers, teacher trainees and the students of other fields of study and find 
five causes which are non-native speaking teacher factor, codability in the native tongue, mobility of stress in English, vowel reduction and pronunciation fossilization. Rahal [4] investigates the problem and propounds the factors behind the fossilized pronunciation of the schwa sound in the speech of ATEL and found three main different pronunciations of the schwa sound as the problem. She also found three main factors behind this problem; L1 Interference, the inconsistency of English vowels and lack understanding of English phonetics. Smaoui and Rahal [5] conducted an experimental study by using the audioarticulation method which is proposed by Demirezen to remedy the fossilization and found that $\mathrm{L} 1$ interference, lack of exposure to L2 input, and the absence of pronunciation teaching methods are the main factors behind the fossilized pronunciation. Amri [6] found that there were eleven fossilized vowel sounds, ten fossilized consonant sounds, eight causes of fossilized pronunciation errors and three processes of how fossilized pronunciation errors occurred. The causes were lack of learning strategies, L1 interference, persistent error, lack of learner self-monitoring, lack of understanding to English pronunciation, lack of correction by the teachers, social influence and the nature of feedback on learners' use of L2. Premarathne [1] explores the reasons for the fossilization of the mid back vowel in the code repertoire of English as Second Language learners in Sri Lanka and found that the lack of awareness of the existence of two distinct vowel sounds in English is the reason.

This research examines the phenomena of fossilization by exploring the external causes of fossilized pronunciation errors employed by English graduate students in classroom discussion at Universitas Negeri Padang by using the external causal factors proposed by Han [7]. They are absence of corrective feedback, lack of input, reinforcement from linguistic environment, lack of instruction, lack of communicative relevance, lack of written input, quality of input and instruction. This research focused on external cause with the expectations that the result can help the other researchers in finding the method to resolve this fossilized pronunciation error and to research the efficient measures to guide learners to develop towards in a positive direction. Furthermore, it is also expected to give the factual picture of this phenomenon to the curriculum designer so that they can solve the problem by redesigning the curriculum and put more attention to the important of pronunciation in learning English. This, then, will help the teachers in dealing with students' fossilization so that they can raise the efficiency of their English teaching work
Table 1. The Taxonomy of External Causal Factors of Fossilization

\begin{tabular}{|l|rl|}
\hline \multicolumn{2}{|c|}{ External } \\
\hline Environmental & 1. & $\begin{array}{l}\text { Absence of corrective } \\
\text { feedback }\end{array}$ \\
& 2. & Lack of input \\
3. & Reinforcement from linguistic \\
& environment \\
& 4. & Lack of instruction \\
& 5. & Lack of communicative \\
& 6. & relevance \\
& 7. & Quality of input \\
& 8. & Instruction \\
\hline
\end{tabular}

\section{METHOD}

This study belongs to descriptive research with a qualitative approach. The qualitative approach is chosen because the researcher wants to study the phenomenon in natural way and directly from the field. In this research, the researcher observed the natural phenomena of fossilized pronunciation errors that happen in the classroom discussion. Descriptive research determines and describes the ways things are. It means this type of research study language in natural setting without intervention or manipulation of variables [8]. This is relevant to this study because this study explores the external causes of fossilized pronunciation errors in natural communication. It means the researcher focuses on describing what has happened and analyzing the data qualitatively. However, the quantitative calculation was used in a small degree since the researcher wanted to find out the number of the percentage of the prominent errors of English pronunciation features and external causal factors to support and justify the result of the descriptive analysis. Moreover, the researcher also determined the number of deviations which can be categorized as fossilization is 5 and considered that errors are fossilized if the errors are repeated and the number of the errors produced is more than the correct ones.

This research used purposive sampling technique in which the subjects of the research (course, class and students) are determined based on the criteria that needed in this research. The idea behind purposive sampling is to concentrate on people with particular characteristics who will better be able to assist with the relevant research [9]. Thus, the participants were selected based on which students produced the fossilized pronunciation errors based on the IPA chart. The participants of this research were 12 graduate students of English Department of Universitas Negeri Padang in the 2019/2020 academic year. The data of this study were the students' utterances in classroom discussion and the information from the interview. The researcher is the primary instrument, as she was the only one who will collect and gather the data to be analyzed. However, the secondary instruments are still needed. The researcher used observation and interview as the research instrument. The observation was used to identify which student employ the fossilized pronunciation error and to find out the prominent errors of English pronunciation 
features that tend to be fossilized. The data were the students' utterance in classroom discussion. Meanwhile, the interview was used to explore the external causes of fossilized pronunciation errors.

The data analyzed based on the result of depth interview. The result of interview was analyzed by following three activities [10]. They are data condensation, data display, and conclusion drawing/verification. In data condensation, there are some steps that researcher did in reduction of the data. First, the researcher transcribed the data recording. Second, the researcher tidied up the data that the researcher collected and grouping the data based on Han's [7] taxonomy of causal factors of fossilization theory. In grouping the data, the researcher followed the description of each indicator. Third, the researcher gave the initial reading for the data. Fourth, the researcher selected the data related to the research topic. Fifth, the researcher coded and bolded the important section of causal factors of fossilization with some codes. In data display, the researcher tried conclude the result of data that have been condensing in table and made a table that have clear information given by the informants. After condensing and displaying the data, the researcher made conclusion and verification of the data. Since it is a descriptive research, the terms of validity and reliability of the instruments and data were known and defined in the term of truth worthiness. The research instruments (observation sheet and interview guideline) have had been validated by two of the English Department lecturers at UNP with an expertise in linguistics. As the relationship between the research questions and the data have had been confirmed when validating the research instrument, the transcription and the data analysis are valid.

\section{RESULT AND DISCUSSION}

To explore the external causes of fossilized pronunciation errors employed by English graduate students in classroom discussion, the taxonomy of external causal factors of fossilization proposed by Han [7] was used for analyzing the data. The taxonomy of external causal factors consists of one subfactor that is environmental. Environmental subfactor consists of seven indicators: (1) absence of corrective feedback, (2) lack of input, (3) lack of communicative relevance, (4) reinforcement from linguistic environment, (5) lack of instruction and instruction, (6) lack written input, (7) quality of input.

The findings showed that all of the indicators are causing the students' fossilized pronunciation errors. Reinforcement from linguistic environment, lack of written input, and lack of instruction and instruction are the prominent causal factors among those seven indicators.
Table 2. Finding of the External Causal Factors employed

\begin{tabular}{|c|c|c|c|}
\hline No & $\begin{array}{c}\text { External Causal } \\
\text { Factors }\end{array}$ & Frequency & Percentage \\
\hline 1 & $\begin{array}{l}\text { Absence of } \\
\text { corrective feedback }\end{array}$ & 6 & 13.33 \\
\hline 2 & Lack of input & 4 & 8.88 \\
\hline 3 & $\begin{array}{l}\text { Lack of } \\
\text { communicative } \\
\text { relevance }\end{array}$ & 6 & 13.33 \\
\hline 4 & $\begin{array}{l}\text { Reinforcement from } \\
\text { linguistic } \\
\text { environment }\end{array}$ & 10 & 22.22 \\
\hline 5 & $\begin{array}{l}\text { Lack of instruction } \\
\& \text { Instruction }\end{array}$ & 7 & 15.55 \\
\hline 6 & $\begin{array}{l}\text { Lack of written } \\
\text { input }\end{array}$ & 9 & 20 \\
\hline 7 & Quality of input & 3 & 6.66 \\
\hline & Total & 45 & 100 \\
\hline
\end{tabular}

The results in table 2 show the external causes of fossilized pronunciation errors employed by English graduate students in classroom discussion. According to the table, there are seven indicators that caused the fossilized pronunciation errors and according to the frequency of the external causal factors; the prominent cause was reinforcement from linguistic environment which was testified by 10 students $(22.22 \%)$, followed by lack of written input 9 students $(20 \%)$, and lack of instruction and instruction, 8 students $(15.55 \%)$. The notable findings of this research are explained below.

\section{Reinforcement from linguistic environment}

The first notable finding from this study is the reinforcement from linguistic environment. The students, as the foreign language learner, mostly get the exposure of English from the classroom, therefore classroom is the only linguistic environment that requires, supposedly, the use of full English from the students. Most of the students explained that when they do pronunciation errors in the class discussion, the environment (teacher or lecturer and other students) did not or rarely give any responses. This is because their environment could still understand them despite the errors in their pronunciation.

Interviewer : When you do a pronunciation error while doing presentation in the class, how is the reaction from the people around you? like from the lecturer, teacher or friends.

$\begin{array}{ll}\text { S15 } & : \text { Just a normal reaction } \\ \text { Interviewer } & : \text { Hm they don't really care huh? } \\ \text { S15 } & : \text { Hmm, it's like they keep it just for } \\ & \text { themselves }\end{array}$

The table above shows that there was no reinforcement from the student's environment to use proper English. It makes the student think that their communication needs have met his or her purposes, which cause the motivation to improve wanes. It is supported by the previous study done by 
Wahyuni et all [11] who say that one of the causes of fossilization is overly compliant interlocutors, teachers, and non-teachers who adapt to the learner's errors. In addition, the rareness of teacher or lecturer in using English and the environment that mostly have improper pronunciation are also the cause of the students' fossilized pronunciation errors.

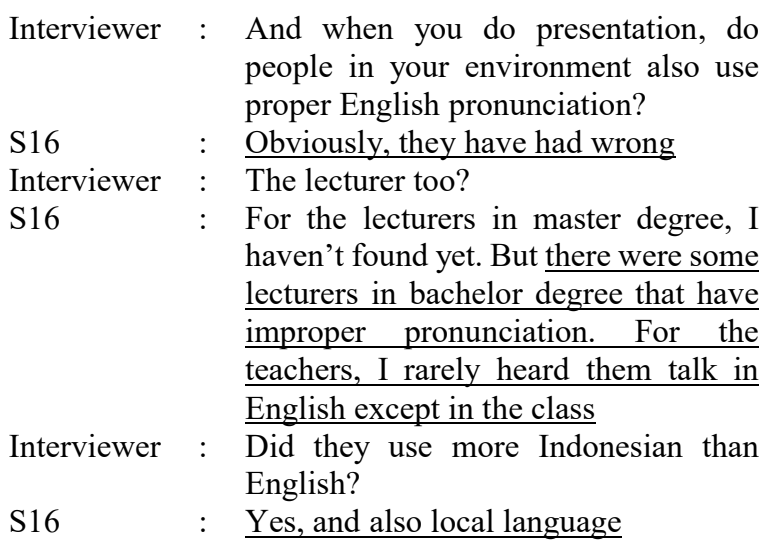

This finding shows that the contingent consequences of communicating are, in fact, an important driving force in language acquisition [12]. The reinforcement includes social reinforcement by even the subtlest reactions of listeners, which affect who we talk to and how and potentially, "automatic" reinforcement by auditory feedback from our own speech [13]. The immersion program (e.g., Harley and Swain, 1978) [14] also includes as the reinforcement from the environment, in which the teachers can simulate an immersion environment by establishing an 'English-only' area in their institutions and by insisting on all communication with them being in English. Yet, if there is a deviant input from the teacher or the peer in immersion program, the stimulus will not have an effect. Those deviant input has been noted as a possible cause of persistent output errors [15].

\section{Lack of written input}

The findings also show that fossilized pronunciation errors are caused by lack of written input. Pronunciation practice is obviously related to speaking and listening, but it is also intertwined with both reading and writing. Practicing spelling-sound correspondences develops greater familiarity with orthographic forms, which helps learners in the process of recognizing written words. Pronunciation (and listening) practice also enhances writing. It can reduce spelling mistakes that are due to inaccurate pronunciation and vice versa, reduce pronunciation errors based on spelling [16]. However, many students stated that they prefer watching than reading literature in English.

$\begin{array}{ll}\text { Interviewer } & \begin{array}{l}\text { How often do you read books or } \\ \text { novels in English? }\end{array} \\ \text { S16 } & : \begin{array}{l}\text { I prefer watching, I just have one } \\ \text { English book }\end{array} \\ \text { Interviewer } & : \text { Is that a novel? } \\ \text { S16 } & : \text { Yes, a novel }\end{array}$

$\begin{array}{ll}\text { Interviewer } & : \text { You don't like reading novels? } \\ \text { S16 } & \frac{\text { I like reading but for novel, the }}{\text { language is hard for me to understand, }} \\ & \text { so I prefer to watch western movies }\end{array}$

\section{Lack of instruction and instruction}

The lack of instruction (references) and instruction (talking about inappropriate or ineffective method used) in teaching pronunciation also caused the fossilized pronunciation errors. Many students said that they did not get the explicit instruction (references and method) in learning pronunciation when they were in primary and middle school. They only got a little amount of implicit instruction in learning pronunciation by integrating it into speaking (e.g., reading text aloud and got corrected).

\begin{tabular}{|c|c|c|}
\hline Interviewer & & $\begin{array}{l}\text { Was there any teacher or lecturer who } \\
\text { teach English focus on pronunciation? }\end{array}$ \\
\hline S14 & . & $\mathrm{Mm}$ \\
\hline Interviewer & & When you were in high school? \\
\hline S14 & & $\begin{array}{l}\text { There was nothing like that, it was just } \\
\text { sometimes when we learned speaking. }\end{array}$ \\
\hline Interviewer & ${ }^{\circ}$ & $\begin{array}{l}\text { Have the lecturer or teacher ever gave } \\
\text { references like book or any other } \\
\text { media that could a... improve your } \\
\text { English pronunciation or fix the error? }\end{array}$ \\
\hline S4 & & $\underline{\text { I think no }}$ \\
\hline Interviewer & & $\begin{array}{l}\text { When in pronunciation course, other } \\
\text { than book, was there any other media } \\
\text { that the lecturer gives? }\end{array}$ \\
\hline S4 & & $\begin{array}{l}\text { Nope, s/he just gave an advice to find } \\
\text { the native speaker to improve the } \\
\text { pronunciation }\end{array}$ \\
\hline
\end{tabular}

Moreover, the explicit instruction that they got when they were in bachelor degree were lack some of the elements such as the authenticity of the references used (mostly only used textbook) and lack practice. They also only got a little amount of implicit instruction when learning pronunciation explicitly.

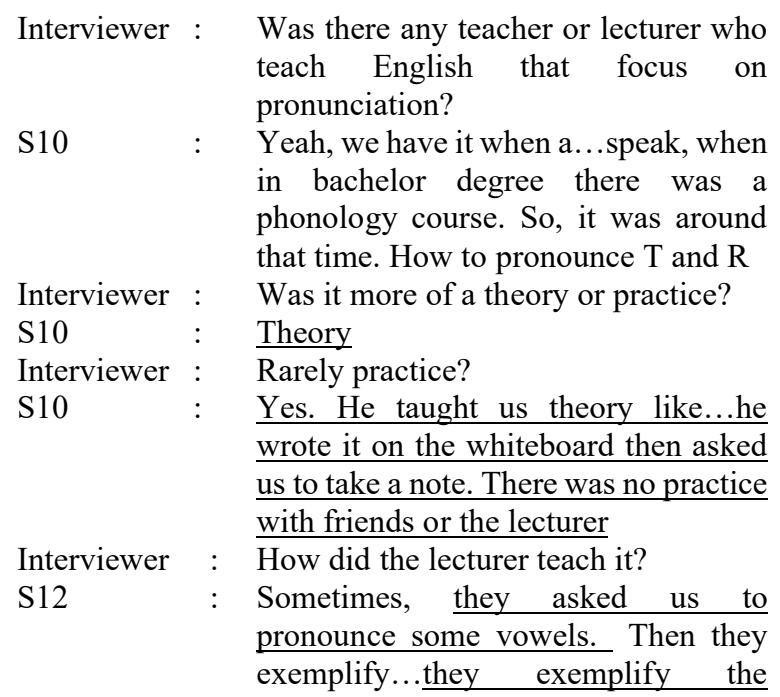


symbol of pronunciation... well... now I already forgot

Interviewer : Was there more... more theory?

S12 : Yes, more lecturing then they exemplify of how to say it...

Interviewer : Less practice huh?

S12 : Yes, less practice

\section{Fossilized errors of English pronunciation features}

This study focuses on segmental (vowel and consonant) and suprasegmental (word stress) features. The result of observation analysis showed that vowels are the most fossilized feature employed by the graduate students in class discussion. The pie chart below summarizes the frequency of fossilized English pronunciation features.

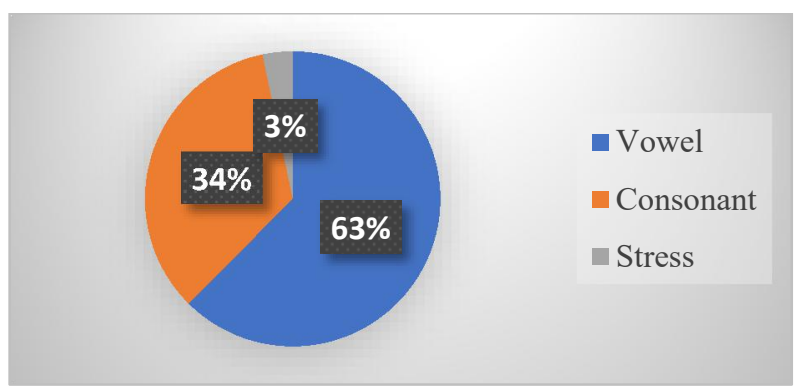

Figure 1. Frequency of fossilized pronunciation features

Moreover, there were 50 fossilized words and 881 errors in total with 550 repetitive errors in vowel, 302 in consonant and 29 in word stress. The words were ranging from common to scientific terms, such as purpose, author, anxiety, thesis and so forth. The researcher analyzed it based on the IPA (International Phonetic Alphabet) chart. The table below is the sample of those fossilized words.

Table 3. The example of fossilized words

\begin{tabular}{|c|c|c|c|c|c|}
\hline No & Words & $\begin{array}{c}I P A \\
\text { Transcripti } \\
\text { on }\end{array}$ & $\begin{array}{c}\text { Students' } \\
\text { Errors }\end{array}$ & $\begin{array}{c}\text { Devia } \\
\text { tion }\end{array}$ & $\mathbf{F}$ \\
\hline 1 & Evidence & 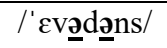 & /'Evididens/ & V & 7 \\
\hline 2 & Thesis & /' $\underline{\boldsymbol{\theta}}$ is $\underline{\underline{\theta}} \mathrm{s} /$ & /'tessis/ & $\mathrm{VC}$ & 21 \\
\hline 3 & Further & 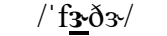 & 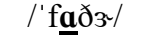 & V & 8 \\
\hline 4 & Support & /so' po.tt/ & /'s $\underline{\Delta}$ po.tt/ & VS & 5 \\
\hline 5 & Reference & 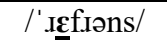 & /'rif.tuens/ & $\mathrm{VC}$ & 5 \\
\hline 6 & Answer & /'æns $\underline{3}$ / & /'ænswer/ & $\mathrm{VC}$ & 7 \\
\hline 7 & Threats & /'0.IEts/ & /'tris/ & $\mathrm{VC}$ & 7 \\
\hline 8 & Comment & /'käment/ & /'koment/ & V & 11 \\
\hline 9 & Author & /' $\underline{\mathbf{p \theta} \mathbf{3}^{2}} /$ & /'sotor/ & $\mathrm{VC}$ & 13 \\
\hline 10 & Anxiety & /æy'zaıti// & /æy'sıeti/ & VC & 21 \\
\hline
\end{tabular}

Mostly, the fossilized words are the words that also exist in Indonesian language (students' L1). Therefore, the students tend to pronounce them same as the Indonesian pronunciation. Consequently, the vowel and consonant sounds that they produce are also the same as the Indonesian sounds. That is the reason why vowel and consonant are the most features that are fossilized. Furthermore, the cause of vowel and consonant errors also applies in word stress error. The word stress patterns of the students' first language (Indonesian) influence the way they put stress on English words. Indonesian word stress patterns are on the penultimate syllable unless the vowel in the penultimate syllable is schwa, in which case stress is final [17].

\section{CONCLUSION}

This research studies the fossilized pronunciation errors of the adult foreign language learners who can be categorized as the advanced learners since they have learned English for more than five years. Yet, the findings lead to the implication in the field of foreign language teaching for secondary and tertiary education since fossilization is the persistent errors occurred in the early acquisition. Raising teachers' or lecturers' awareness of the consequences of neglected student pronunciation errors and incompetence of the learning methods or reference used as well as the students' awareness of the negative affect of fossilized pronunciation errors to the stigmatization of their proficiency and professionalism. The findings also show that there is a lot of homework for curriculum developers to pay more attention to what kinds of instruction can foster student language development, especially in pronunciation. The result of the study also invites the researchers to investigate what methods can remedy or prevent fossilization. Overall, the people involved in this field should take this issue into account.

\section{REFERENCES}

[1] K. Premarathne, "Exploring the Reasons for the Fossilization of Phonological Errors: A Case Study of the substitution of/o/for/o/by English as Second Language Learners in Sri Lanka," Advances in Language and Literary Studies, vol. 9, no. 4, pp. 105-110, 2018, ISSN: 2203-4714.

[2] M. Demirezen and E. Kot, "Collegial Reactions to Faulty Pronunciation of Teachers in relation to English Language Teaching. Procedia Social and Behavioral Sciences 232, p. 471-478, 2016, doi: 10.1016/j.sbspro.2016.10.064

[3] M. Demirezen, "The Causes of the Schwa Phoneme as a Fossilized Pronunciation Problem for Turks," Procedia Social and Behavioral Sciences 2, p. 15671571, 2010, doi: 10.1016/j.sbspro.2010.03.237

[4] A. Rahal, "The Fossilized Pronunciation of the Schwa Sound / o/ in the Speech of Advanced Tunisian English Learners: Problem and Causes," International Journal of Humanities and Cultural Studies (IJHCS), vol. 1, no. 1, pp. 1-6, 2014, ISSN 2356-5926

[5] C. Smaoui and A. Rahal, The Fossilized Pronunciation of the /3:/ Sound in the Speech of 
Intermediate Tunisian English Students: Problem, Reasons and Suggested Solution," International Journal of English Language \& Translation Studies, vol. 3, no. 1, pp. 70-79, 2015, ISSN:2308-5460

[6] F. R. Amri, "Fossilized Pronunciation Errors Committed by the First Year Students of The English Graduate Program of State University of Padang Registered in 2014 Academic Year During Class Discussion," Unpublished thesis, Universitas Negeri Padang, Padang, 2015.

[7] Z. Han, "Fossilization: From Simplicity to Complexity," International Journal of Bilingual Education and Bilingualism, vol. 6, no. 2, pp. 95128, 2003.

[8] A. Y. Putri, "An Analysis of Using Code Switching in English-Arabic Daily Conversation of Dormitory Students at MAN Koto Baru Padang Panjang," Unpublished thesis, Universitas Negeri Padang, Padang, 2016.

[9] I. Etikan, S. A. Musa and R. S. Alkassim, "Comparison of Convenience Sampling and Purposive Sampling," American Journal of Theoretical and Applied Statistics, vol. 5, no. 1, pp. 1-4, 2016, doi: 10.11648/j.ajtas.20160501.11.

[10] M. B. Miles, A. M. Huberman and J. Saldana, Qualitative Data Analysis: A Methods Sourcebook (3rd ed), USA: SAGE Publication, Inc, 2014.
[11] D. Wahyuni, Mukhaiyar and H. Syarif, "Fossilized Spelling Errors in Paragraph Writing Committed by the English Department Students at the Faculty of Teacher Training and Education of Bung Hatta University," Journal English Language Teaching (ELT), vol. 1 no. 1, pp. 65-78, 2013.

[12] B. F. Skinner, Contingencies of Reinforcement: A Theoretical Analysis, USA: B. F. Skinner Foundation, 2013.

[13] A. I. Petursdottir and J. R. Mellor, "Reinforcement Contingencies in Language Acquisition: Implications for Language Intervention," Policy Insights from the Behavioral and Brain Sciences, pp. 1-8, 2017, DOI: 10.1177/2372732216686083.

[14] B. Harley and M. Swain, "An Analysis of the Verb System Used by Young Learners of French," Interlanguage Studies Bulletin, vol. 3, no. 1, pp. 3579, 1978.

[15] D. Larsen-Freeman and M. Long, An Introduction to Second Language Acquisition Research, New York: Longman, 1991.

[16] I. Darcy, "Powerful and Effective Pronunciation Instruction: How Can We Achieve It?," The CATESOL Journal, vol. 30, no. 1, pp. 13-45, 2018.

[17] E. van Zanten and R. Goedemans, "Prominence in Indonesian: Stress, phrases, and boundaries," Wacana, vol. 11, no. 2, p. 197-225, 2009. 